\title{
THE PROBLEM OF NON-FORMAL ADULT EDUCATION QUALITY SERVICE PROVISION IN LOCAL MUNICIPALITIES OF LITHUANIA
}

\author{
Irena Zemaitaityte \\ Mykolas Romeris University, Lithuania \\ Alina Petrauskiene \\ Mykolas Romeris University, Lithuania
}

\begin{abstract}
This article analyzes one of the most important and, simultaneously, the most problematic factors in the development of adult education as the implementation quality of Non-formal Adult Education (hereinafter NAE) at the local government level. The aim of this article is to reveal the understanding of Lithuanian municipal non-formal adult education coordinators about improving the quality of non-formal adult education services. The study has centered on a focus group (12 people) in which Lithuanian nonformal adult education coordinators from different municipalities discussed and shared their diverse opinions. According to the focus group participants, the quality assessment of educational services in local communities is required by the institutions or foundations financing the services, which at the same time indicate the criteria for assessing the quality of services and their fulfillment when reporting on the implementation of educational services. According to the participants of the study, Lithuanian municipalities should have more power in decision making on planning educational programs and services to meet the needs of the local population; they should expect stable funding guarantees from state institutions, which must first and foremost be interested in improving non-formal education services quality assessment.
\end{abstract}

Keywords: Local municipalities, non-formal adult education, quality of educational services.

\section{Introduction}

Education quality assurance in the system of education in Lithuanian is one of the priority goals in the implementation of education reform. The quality of education is identified as a Government priority for the implementing of education reform as is indicated in the Lithuanian Progress Strategy "Lithuania 2030" (2012), in the State Education Strategy for 20132022 (2013). Researchers (Barnett, 2009; Ruževičius, 2006; Želvys, 2003) approach the quality of education in multiple ways: it is seen as mastery, 
compliance with the requirements of the task; quality is also a perfection, which is achieved when the result meets the needs of learners, standards and goals. The growing public interest in lifelong learning calls for a stronger focus on non-formal adult education (further NAE). State regulation and ensuring legal, systemic preconditions for the provision of non-formal education services are necessary for all social groups to be involved in non-formal education. The issue of quality assessment of educational activities is particularly relevant in the implementation of non-formal adult education. The state in its attempt to ensure the accessibility of non-formal education regulates by law that the provider of non-formal adult and continuing education is responsible for the quality of non-formal education. Attempts are often made to measure the quality of non-formal adult education on the basis of set guidelines for quality non-formal education. Criteria, assessment, control and supervisionbased quality definition and assurance can obstruct achieving of the main goals of non-formal education, and can make non-formal education less flexible and attractive to learners. The procedure for quality improvement of non-formal adult education, assessment of activities, external evaluation, assessment of participants' progress and achievements financed from the state and / or municipal budgets are established by state institutions. Quality assurance of any other non-formal adult education provided at the expense of learners is not regulated in any way in Lithuania and could apparently be a matter of agreement between all stakeholders.

Some empirical research has been conducted in Lithuania on certain issues of adult education: on the state of non-formal adult education and the attitudes of the population and employers towards adult education (Tamošiūnas, Šutinienè, Filipavičienè, \& Guseva, 2005), analysis of nonformal adult learning concepts in the context of lifelong learning (Linkaityte, Šuliakaite, \& Navikienè, 2011), and on non-formal adult education in municipalities (Penkauskienè, 2017). However, there is a lack of research that would delve into the preconditions for improving the quality of non-formal adult education in Lithuania.

The aim of this article is to reveal the understanding of Lithuanian municipal non-formal adult education coordinators about improving the quality of non-formal adult education services. The following research question is asked: What obstacles and preconditions for the improvement of the quality of NAE services do the municipal coordinators based on their experience identify? 


\section{The Concept of the Education Quality}

The concept of quality in the context of education has been used since a relatively recent time and it has moved into education from management. The shift of terms (quality, demand, supply, standards, service provider, etc.) from business to education can be explained by the onset of globalization in societies with fewer value selection criteria and replaced by free market forces based on competition, price, benefits and calculation. Literature provides diverse definitions of quality but many of them share a similar content: quality can be defined as meeting expectations, meeting and exceeding customer requirements, compliance with standards and specifications, suitability for use, degree of customer satisfaction (Aniskina, 2015; Latchem, 2014; Želvys, 2003). The UNESCO concept of the quality of education distinguishes two levels: the internal - the level of the learner operating in a learning environment, and the external - the level of the education system that creates and supports learning experiences. Increase in the accessibility of education might be augmented along with the measures to improve the quality of education (UNESCO, 2016). The Law on Education of the Republic of Lithuania (2011) states that the concept of the quality of education is developed by the society, education participants and education management entities. The quality of education is linked to the implementation of educational expectations that satisfy both consumers and education providers. R. Želvys et al. (Želvys, Dukynaite, Vaitekaitis, \& Jakaitienè, 2020) maintain that the quality of education has always been understood differently, as perceptions of quality depend on both the subjective attitudes of those who evaluate it and the context in which that evaluation takes place. Quality implementation encounter problems of its different perceptions. Understanding the quality of service providers and their users can vary and be seen as: quality as exclusivity, quality as compliance with standards, quality as a level of customer satisfaction, quality as an agreement, and quality as efficiency in achieving goals. Thus, the quality of education depends on what goals are set for education and how successfully they are achieved (Želvys et al., 2020).

According to A. Helmke (2012), the term "quality in education" can have different meanings. It distinguishes two important definitions of quality:

- quality as an inherent feature or characteristic of an object or phenomenon;

- quality as the excellence of an object or phenomenon, uniqueness, indicating the degree of goodness of the object or phenomenon.

Thus, definitions of quality depend on the value system, traditions, needs of society and indicate what, in the opinion of society and its group, an object or process should be (Barnett, 2009). Although not all of the concepts listed 
Zemaitaityte \& Petrauskiene, 2021. The Problem of Non-Formal Adult Education Quality Service Provision in Local Municipalities of Lithuania

can be applied to the context of education, several of them are used to analyze the quality of education: quality is meeting certain requirements and standards and quality is understood as compliance with the purpose. Quality is usually described by a number of key criteria, which are expressed in terms of indicators. The established quality criteria and indicators help to achieve and adhere to the principles of objectivity, accessibility, transparency and reliability of non-formal and informal learning achievement assessment. At each stage of the evaluation process, the evaluation criteria and indicators should be known in advance, the criteria should be easily established, and the indicators should be measurable (Stasiūnaitienè \& Piščalkienè, 2012). According to S. Sjöberg (2019) it is rather problematic to evaluate the quality of education with indicators that are universal, i. y. applicable to all countries, regardless of education systems, social characteristics, culture, customs and traditions, living conditions, production methods, etc. R. Laužackas maintains that standards "help to ensure the quality of teaching. Standards always express the teaching guidelines, tasks, ideals that are pursued in the teaching process. They set $<\ldots>$ quality criteria” (Laužackas, 2000, p. 38). According to R. Želvys (2003), the development of criteria, standards and methods for quality assessment is the first stage in the process of control. Thus, in this case, quality assurance is related to control, as well as performance quality assessment (Želvys, 2003).

\section{Research Methods}

The choice of the qualitative research methodology was determined by the purpose of the research. For the qualitative research, the focus group method was chosen, reflecting with the study participants their work experience (Morgan, 2010). Article 8 part 2 of the Law on Non-formal Adult Education and Continuing Education of the Republic of Lithuania (2014) obliges municipalities to prepare an action plan for non-formal and informal adult education and to appoint a coordinator for its implementation. 12 Lithuanian non-formal adult education coordinators (10 women and 2 men) from different Lithuanian municipalities with 2 - 10 years of experience in planning, organizing and coordinating adult non-formal education services participated in the study 2020.

The participants in the study signed an informed consent form, by which they confirmed their voluntary participation in the study, and the researchers were obliged to ensure the confidentiality of personal data.

At the stage of data analysis, the discussion record was transcribed. The result of data transcription is a text which was deemed to be analyzed by the qualitative content analysis (Žydžiūnaite \& Sabaliauskas, 2017) - a creative 
thinking process to decode the meanings in the text, understand and identify the situation and development perspectives.

\section{Results}

\section{Complications and Conditions for the Non-formal Adult Education Quality Enhancement}

The analysis of the content of the study participants' interview data allowed to highlight the problems of quality assurance of NAE services implemented in the regional municipalities. The evaluation of the quality of NAE services is recognized by municipal coordinators as an area of responsibility for the activities they supervise, the implementation of which requires certain decisions at the governmental and municipal levels. The relevance and perspective benefits of the assessment of the quality of services in the NAE are acknowledged, but the development and improvement of the quality of services for the population is obstructed by: 1) planning of NAE services (covering the activities of targeted educational, self-expression, qualification improvement, general competence development programs) in municipalities without financing guarantees; (2) information dissemination, promoting various planned and implemented NAE training services to the population; (3) unclear criteria for assessing the quality of different NAE services.

Lack of stable financing of NAE services in municipalities. The annual planning and implementation of NSD programs is different in the countries' regional municipalities, small and large, according to the study participants. In some municipalities, the administrations annually allocate funds for the organization of non-formal education services for the local population, in others, when drawing up perspective plans for the NSD, no stable guaranteed funding is provided or only minimal financial resources are allocated.

"Here with those plans today someone said very much to the point that they did all formally, but if the plan is approved without money, it's already funny here, or invests some 2,000 let's say to a competition of non-formal education programmes. And learning, which we are implementing, is extended for the whole week, so how will you act without money. You will not do anything without money".

"There are very different municipalities - there are some with 17 thousand planned, there are some who get nothing at all, and the plan needs to be implemented, plans are approved without money". 
Zemaitaityte \& Petrauskiene, 2021. The Problem of Non-Formal Adult Education Quality Service Provision in Local Municipalities of Lithuania

Municipal coordinators annually submit NAE event / measure plans to municipal administrations, prepare projects and submit their applications to national funds, but this does not guarantee stable funding.

„We write and submit projects, then we saw that we are not included as potential applicants, dropped out of municipal budget institutions, then, we started through NGOs, then there was a problem recruiting people, and when those funds no longer reached us and... ". The organization of NAE services in individual regional municipalities is fragmented, depending on funding resources, and without project funding, the supply of training services becomes very limited. In the absence of financial resources, municipal administrations seek to coordinate and mobilize initiatives from private, non-governmental or public NAE training providers (for example, by organizing a NAE training week in the municipality). In other municipalities, the annual NAE plan includes educational programmes planned by the service providers - partners and their activities, the financing of which is not the concern of the local government, but of other private or public service providers: "And now how does the plan emerge, do you know this, for the training week? So they call service providers: "what shall you do, what shall you do", and add up, they make it up, add up, and add up from all partners add up...".

The lack of dissemination of training, self-expression, general competencies, organization of qualification improvement services is determined by the disturbances of coordination of information and advertising about NAE services in regional municipalities. The coordinators noted that the population lacked concentrated information about the services provided or planned to be implemented in the NAE and their providers in regional cities, towns or rural communities. There is also a lack of a variety of forms of information dissemination, relevant messages for groups of the population on the websites of individual city municipalities, on television, in gathering places (church, library).

"Now we say, an individual wants to... it is December month, I want to study, where can I now find information in $X$ city where about what is happening is posted ... there is no such thing as a common [place], what is happening... there is what is happening there, there, so where am I to look for... So everyone boils in their own juice, there is no common place ".

"We put up information on education and training of cultural workers, but for non-formal education alone there is no dissemination on the website there is no place, for example, where pottery classes take place, some lectures, so all the information should be posted, everywhere - even in the church. If you just put it on the internet, it won't work here".

In the municipalities of smaller cities, where the position of coordinator has not been established, there is no one responsible for collecting, storage, 
dissemination of the information, and administration of the population and providers of NAE services. Then it appears that" in this district NAE, in my view, it takes place, only in each individual institution, without any manner of cooperation." The participants of the research - coordinators noticed a certain isolation and closedness of the providers of NAE services in the regions ("everyone boils in their own juice, there is no common place... it is like competition") and competition, although they are acquainted with each other. Municipal administrations tend to require indicators and accountability from private and public NAE service providers, but do not care about their mobilization and coordination in order to use organizational resources efficiently and rationally.

"And now I hear, everywhere municipal politicians demand indicators, accountability of institutions, if they can do an event together, it is a no, but when done separately, then there is a problem of attracting people, and organizational resources."

Different funders and service providers of NAE services have different assessments of the quality of NAE services. According to the coordinators, the evaluation of the quality of organized NAE services is required by government institutions and foundations that provide funding. Funding authorities usually specify service quality assessment criteria and require a report. In such cases, the implementation of the NAE service quality assessment becomes the obligation of the service providers.

"But who can ask me about quality, and who will need it? Again, for those who give money. I myself encountered the very problem when we prepared [...], then came a call for me from the municipality and an question how do you ensure the quality of NAE programmes? That's what I'm writing at the end of my training."

"If we take the law, it is written there, we have to ensure the quality of NAE programmes, I imagine that the quality criteria must be universal. "

The coordinators believe that universal principles and criteria for assessing the quality of NAE services should be defined and applied in all municipalities of the country. Municipalities that have made a decision on the financing of NAE programmes / training services, their implementation and quality assessment could put to life this consistently on an annual basis, as provided for in the Non-formal Adult Education Law (2018) and analyze the results and draw guidelines for the development of services for local residents.

"...you know, you can talk about quality first and demand it when you pay one money, remuneration. Then there may be planning, setting quality criteria...“ 
Zemaitaityte \& Petrauskiene, 2021. The Problem of Non-Formal Adult Education Quality Service Provision in Local Municipalities of Lithuania

"Someone has to say what is the quality of NAE programmes, it is not for me to do it, in one municipality or another municipality the same criteria... for the municipality to decide, if this program is of quality and that is not."

Municipalities monitor the quality of the implementation of NAE services in a fragmented and formal manner, applying minimum quantitative objective measurement tools, collecting data on service costs, number of service providers and recipients, age, gender, etc.

"They will carry out that monitoring, for example, the municipality, it will say what, how many were involved, they will ask of finances, age, gender, if it is needed by the Institute for Gender Equality, it will be a quantitative assessment of quality".

"We are accustomed to having only objective quality measurement figures“.

Subjective qualitative evaluation of services, involving service users participants of various training programmes, creating reflection spaces, although recognized by the coordinator as essential in adult education, is not defined and, therefore, not developed. Coordinators are of the opinion that, in the first instance, the quality of the NAE training should be the responsibility of the service organization, which provides quality assessment criteria. "We also write that the provider is responsible for the quality of the training. I cannot tell if the library has conducted good training or poor training. If people come for the second time, then all is fine".

On the other hand, in the absence of a market for NAE services in the country that would operate on the basis of a formalized and defined quality assessment, municipal administrations have no guarantees to purchase the best quality services. The relevance of the competence of lecturers who are able to conduct trainings for adult groups is also recognized (... if a lecturer does not work well, they will not be invited. If they meet the needs of clients, their service is quality services) as an essential criterion for ensuring service quality.

\section{Discussion and Recommendations}

The main organizers and coordinators of NAE services for residents in Lithuania are regional city municipalities and their councils. Municipalities finance and plan NAE for separate population groups, they may provide NAE services themselves or delegate NAE services to other providers of NAE, i.e.: private institutions, non-governmental or public organizations (Order of the Minister of Education and Science of the Republic of Lithuania 2017). In the absence of an institution in Lithuania that would be responsible and have the competence to perform the functions of quality assessment of non-formal education and could provide methodological assistance to municipalities and 
coordinators working there, ensuring the quality of services becomes difficult. The results of this study reveal that the evaluation of the quality of NAE programmes and services implemented in municipalities is formal and fragmentary, without the active involvement of service users in the analysis of quality improvement and anticipation of perspectives. Municipal coordinators do not have sufficient resources, assistance and tools to mobilize service providers (Penkauskienè, 2017), nor to address quality assessment and improvement issues. Local authorities are called upon by politicians to become responsible not only for stabilizing the financing of NAE, controlling expenditures, but also for attracting additional financial and private sector resources to develop quality education and access to services for the benefit of local communities and regional social and economic development (Butviliené, 2014; Kurawa 2020; Rawat, Bouchon, \& Nair 2015).

On the other hand, it is difficult for municipalities to independently achieve education quality and excellence standards due to the strict approach and control of the central government, without targeted methodological assistance in the issues of education quality assessment and improvement in a regional context (Smalskys, Stasiukynas, Gavkalova, \& Lasevičiūté, 2019). Next, the local government administration is more focused on financing formal education and in-service training and ensuring accessibility to meet the needs of the labor market than on the development of other NAE services focused on the development of individual groups`self-development / growth of general personality competencies (Butvilienè, 2014). In order to develop the market of the NAE sector and improve the quality of services, the principles of quality assessment must be transparent and systematically and consistently applied. The quality of NAE services is relative and depends on many things: context and conditions, rapidly changing needs of adult education, adult motivation and training tools, availability of services (Prakapas \& Devenyte, 2014), therefore, it can be difficult to assess. However, there are some important principles that providers / organizers of education in the public and private sectors should follow: a) the relevance of the offered training to the needs of the target groups; b) exposing learners to the personal and social benefits of adult education; (c) strengthening partnerships with other education providers; d) cooperation with business and non-governmental organizations (NGOs); e) the use of online tools both in the development of adult education programmes and in raising awareness of the meaning of such education (in line with Strategies for improving participation and awareness of adult learning, COM, 2012). 
Zemaitaityte \& Petrauskiene, 2021. The Problem of Non-Formal Adult Education Quality Service Provision in Local Municipalities of Lithuania

\section{Conclusions}

The study revealed that the assessment of the quality of implementation of non-formal adult education activities differs in individual municipalities. Institutions or foundations that provide funding for training shall also specify quality evaluation criteria and require a report on the implementation of the training. Thus, the issue of quality assessment of training implementation is inseparable from the institution financing the training, in other words, when allocating funding for training implementation, quality assessment is also required. The problematic assessment of the quality of the implementation of non-formal adult education in the regions of the country is also related to the situation of the local municipality, when adult education activities are planned without funding guarantees or only minimal financial resources are allocated for population training. In the absence of guaranteed funding for adult learning activities, the quality assessment of adult learning is not formalized, and the criteria for quality assessment remain unclear. Therefore, it is necessary to enable Lithuanian municipalities to make decisions on the financing, implementation and quality assessment of planned adult learning programmes / activities, which would respond to the legal acts adopted in Lithuania and the needs of adults.

\section{References}

Aniskina, N. (2015). Quality Assurance in Continuing Adult Education: From the European to the National Level. International Journal for Quality Research, 9(3), 373-390.

Barnett, R. (2009). Knowing and becoming in the higher education curriculum. Studies in Higher Education. 34(4). Retrieved from: https://www.tandfonline.com/ doi/abs/10.1080/03075070902771978

Butvilienè, J. (2014). Neformalusis suaugusiujų švietimas Lietuvoje: valstybinis ir privataus mokymo sektoriai. Daktaro disertacija. Vilnius: Lietuvos socialinių tyrimų centro Sociologijos institutas.

Helmke, A. (2012). Pamokos kokybe ir mokytojo profesionalumas: diagnostika, vertinimas, tobulinimas. Vilnius: Standartų spaustuvè.

Kurawa, G. (2020). Study Circle as an Innovative Tool for Promoting Lifelong Learning and Community Empowerment. Teaching and Learning Strategies for Sustainable Development. DOI: https://doi.org/10.1108/S2055-364120200000019014

Latchem, C. (2014). Informal Learning and Non-Formal Education for Development. Journal of Learning for Development, 1(1). Retrieved from: http://oasis.col.org/bitstream/ handle/11599/854/Latchem\%20_\%20Journal\%20of\%20Learning\%20for\%20Developm ent\%20-\%20JL4D.pdf?sequence $=1$

Laužackas, R. (2000). Mokymo turinio projektavimas: standartai ir programos profesiniame rengime. Kaunas: VDU profesinio rengimo studijų centras.

LIETUVOS PAŽANGOS STRATEGIJA „LIETUVA 2030. (2012). Retrieved from: https://eseimas.lrs.lt/portal/legalact/lt/tad/tais.425517 
Lietuvos Respublikos švietimo ir mokslo ministro 2017 m. birželio 28 d. isakymas Nr. V-536 „Dèl Mokymosi visa gyvenima plètros 2017-2020 metu veiksmu plano patvirtinimo” Retrieved from: https://e- seimas.lrs.lt/portal/legalAct/lt/TAD/ 8e9c7f545d0511e 7a53b83ca0142260e?jfwid=f4nne5tdt

Morgan, D. L. (2010). Reconsidering the Role of Interaction in Analyzing and Reporting Focus Groups. Qualitative Health Research. 20(5), 718 -722.

Tamošiūnas, T., Sutinienė, I., Filipavičienè, \& Guseva, O. (2005). Neformaliojo suaugusiuju švietimo būkle ir gyventojų bei darbdaviu požiūrị i suaugusiuju švietima. Tyrimo ataskaita. Retrieved from: https://www.kpmpc.lt/kpmpc/tyrimai-ir-apzvalgos/ suaugusiuju-svietimas-2/

Linkaitytė, G., M., Šuliakaitè, A., \& Navikienė, Z. (2011). Neformaliojo suaugusiujų mokymosi sampratų analizè mokymosi visą gyvenimą kontekste. Retrieved from: https://www.kpmpc.lt/kpmpc/tyrimai-ir-apzvalgos/suaugusiuju-svietimas-2/

Neformaliojo suaugusiuju švietimo ir tęstinio mokymosi įstatymas. (2014). Retrieved from: https://e-seimas.lrs.lt/portal/legalAct/lt/TAD/ce0399a00cd411e497f0ec0f2b563356

Neformaliojo suaugusiuju švietimo ir tęstinio mokymosi istatymo. (2018). Nr. VIII-822 pakeitimo istatymo projektas (nauja redakcija) Retrieved from: https://eseimas.lrs.lt/portal/legalAct/lt/TAP/3b5630b0e36011e8bcacfff937113a43

Penkauskienè, D. (2017). Neformaliojo suaugusiuju švietimo ir tęstinio mokymosi koordinavimas savivaldybėse: koordinatoriu veiklos apžvalga. Kvalifikacijų ir profesinio mokymo plètros centras, Vilnius. Retrieved from: https://www.kpmpc.lt/kpmpc/wp-content/uploads/2015/08/Koordinatori\%C5\%B3veiklos-ap\%C5\%BEvalga.pdf

Prakapas, R., \& Devenytè, J. (2014). The accessibility of learning tool for non-formal adult self-education in entrepreneurship. Societal Studies, 6 (2), doi:10.13165/SMS-14-6-209, ISSN 2029-2244 (online) Retrieved from: https://www3.mruni.eu/ojs/societalstudies/article/view/1882/3740

Rawat, K., Bouchon, F., \& Nair, V. (2015). Innovative practice in education to empower rural communities: A case study of a non-formal education school in Thailand. Worldwide Hospitality and tourism Thems, 7(5). Retrieved from: https://www.emerald.com/ insight/content/doi/10.1108/WHATT-06-2015-0027/full/html

Sjöberg, S. (2019). The PISA-syndrome - How the OECD has hijacked the way we perceive pupils, schools and education. Confero: Essays on Education, Philosophy and Politics, 12-65.

Smalskys, V., Stasiukynas, A., Gavkalova, N., \& Lasevičiūtè, U. (2019). Problems in managing the implementation of education policy in Lithuania: The role of small municipalities. ESPACIOS, 40(26), 11. Retrieved from: https://www.revistaes pacios.com/a19v40n26/19402611.html

Stasiūnaitienè, E., \& Piščalkienè, V. (2012). Studentų patirtinis mokymasis mokslo taikomųju tyrimu praktikoje. Sveikatos mokslai, 22(5), 40-45.

Strategies for improving participation in and awareness of adult learning, COM. (2012). European Union. Retrieved from: https://www.ab.gov.tr/files/ardb/evt/1_avrupa_birligi/ 1_9_politikalar/1_9_4_egitim_politikasi/ec_guide_adult_learning.pdf

VALSTYBINE ŠVIETIMO 2013-2022 METU STRATEGIJA. (2013). Retrieved from: https://eseimas.lrs.lt/portal/legalAct/lt/TAD/TAIS.463390

UNESCO. (2016). Education 2030: Incheon declaration and framework for action for the implementation of Sustainable Development Goal 4. Retrieved from: https://unesdoc.unesco.org/ark:/48223/pf0000245656 
Zemaitaityte \& Petrauskiene, 2021. The Problem of Non-Formal Adult Education Quality Service Provision in Local Municipalities of Lithuania

Žydžiūnaite, V. \& Sabaliauskas, S. (2017). Kokybiniai tyrimai: principai ir metodai: vadovèlis socialiniu mokslu studiju programu studentams. Kaunas: VDU.

Želvys, R. (2003). Švietimo organizaciju vadyba. Vilnius: Vilniaus universiteto leidykla.

Želvys, R., Dukynaitè, R., Vaitekaitis, J., \& Jakaitienè, A. (2020). Švietimo tikslų transformacija i rezultatų rodiklius Lietuvos ir tarptautinèje švietimo politikoje. Acta Paedagogica Vilnensia, 44, 18-33. 


\section{SABIEDRĪBAS VESELĪBA UN SPORTS \\ Public Health and Sport}


